\title{
Correction to: Comparative analysis of powdery mildew resistant and susceptible cultivated cucumber (Cucumis sativus L.) varieties to reveal the metabolic responses to Sphaerotheca fuliginea infection
}

Peng Zhang ${ }^{*}$, Yuqiang Zhu and Shengjun Zhou

Correction to: BMC Plant Biol (2021) 21: 24

https://doi.org/10.1186/s12870-020-02797-3

Following publication of the original article [1], the authors identified an error. Figures 6 and 7 are the same. The correct figure 7 is given below.

The original article [1] has been corrected.

Correct Figure 7:

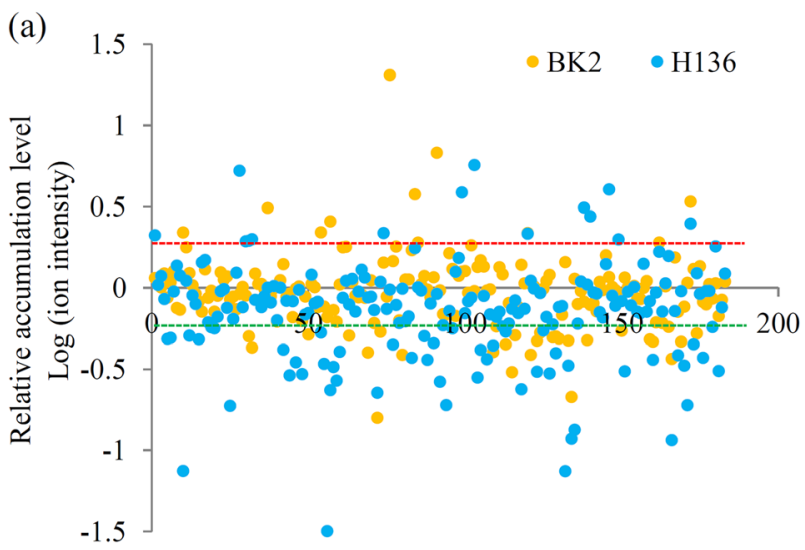

The original article can be found online at https://doi.org/10.1186/s12870020-02797-3.

* Correspondence: zhangp@zaas.ac.cn

Institute of Vegetable, Zhejiang Academy of Agriculture Sciences, Hangzhou, China

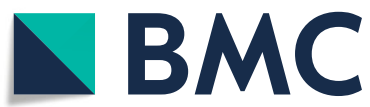

(c) The Author(s). 2021 Open Access This article is licensed under a Creative Commons Attribution 4.0 International License, which permits use, sharing, adaptation, distribution and reproduction in any medium or format, as long as you give appropriate credit to the original author(s) and the source, provide a link to the Creative Commons licence, and indicate if changes were made. The images or other third party material in this article are included in the article's Creative Commons licence, unless indicated otherwise in a credit line to the material. If material is not included in the article's Creative Commons licence and your intended use is not permitted by statutory regulation or exceeds the permitted use, you will need to obtain permission directly from the copyright holder. To view a copy of this licence, visit http://creativecommons.org/licenses/by/4.0/ The Creative Commons Public Domain Dedication waiver (http://creativecommons.org/publicdomain/zero/1.0/) applies to the data made available in this article, unless otherwise stated in a credit line to the data. 